\title{
Minimizing systemic infection during complete parenteral alimentation of small infants
}

\author{
R. NELSON \\ From the Department of Paediatrics and Child Health, University of Birmingham
}

\begin{abstract}
Nelson, R. (1974). Archives of Disease in Childhood, 49, 16. Minimizing systemic infection during complete parenteral alimentation of small infants. A regimen of parenteral alimentation for infants was designed to eliminate as many factors responsible for infection as possible.

The most important features of the feeding regimen were as follows. (1) Infants were fed via indwelling silastic catheters inserted into the superior vena cava or the right atrium by a cutdown operation. (2) The parenteral feeding was fat free to simplify the administration system. Y connectors and 2- or 3-way taps were avoided. (3) Extreme care was taken of junctions within the infusion system. Only certain members of the hospital staff were allowed to break such junctions, e.g. during the changing of packs of solution or of the giving sets. These junctions were sprayed with antibacterial aerosols. (4) The hypertonic solutions of nutrients were prepared in plastic packs, which do not require ventilation. The infusion system was therefore not contaminated by the entry of unsterile outside air. (5) The infused solutions were passed through $0.22 \mu \mathrm{m}$ millipore filters before entering the patient's blood stream.

There was an infection rate of $9 \%$ which was less than the 25 to $45 \%$ infection rate previously reported during parenteral feeding through indwelling venous catheters, and is also less than that associated with ventriculoatrial shunts for hydrocephalus. There was no case of systemic candidiasis, which is the most frequent and most serious infection associated with parenteral feeding.
\end{abstract}

Systemic infection may complicate all forms of parenteral infusions, particularly those using intravenous catheters (Banks et al., 1970). During intravenous alimentation the risk of septicaemia is particularly great (Boeckman and Krill, 1970). If extreme care is not taken, the infection rate during parenteral feeding can become so high that it precludes this form of therapy in all but the most critically ill infant.

A regimen of parenteral feeding has been designed to eliminate as many as possible of the potential avenues of such infection and has been used during the past 10 months to treat 17 infants, all aged less than 12 months. Details of this regimen and the rate of infection experienced are presented.

\section{Parenteral alimentation regimen}

The method of parenteral alimentation to be described was used for the prolonged feeding of very small infants. Such patients frequently require feeding through a central venous catheter as available peripheral veins

Received 4 July 1973. rapidly become unusable. Because of the known dangers, central venous catheterization should be performed only when other methods of feeding have failed.

A fat-free system was used to simplify administration? and to minimize possible infection sites. It is well established that such fat-free parenteral feeding will support optimum growth and development of small infants over several months (Wilmore and Dudrick, 1968).

Preparation of parenteral solutions. Two basic solutions were used. Solution I contained over $900 \mathrm{cal} / 1$. as $18 \%$ glucose and $3.6 \%$ protein hydrolysate. It $\sigma$ consisted of a mixture of $200 \mathrm{ml} 50 \%$ glucose and $500 \mathrm{ml} \mathrm{N}$ $5 \%$ protein hydrolysate $/ 5 \%$ dextrose . Solution II N contained $660 \mathrm{cal} / 1$. as $12.5 \%$ glucose and $4.1 \%$ protein hydrolysate. It was a mixture of $100 \mathrm{ml} \mathrm{50 \%} \mathrm{glucose}$ and $500 \mathrm{ml} 5 \%$ protein hydrolysate $/ 5 \%$ dextrose.*

Both solutions were prepared in plastic transfer packs $\dagger$ Ф which do not require ventilation. The essential amino $\stackrel{\mathcal{C}}{-}$

$\star$ Amigen/dextrose solution, Baxter (Travenol Division), Thetford, Norfolk.

†TAI Transfer Packs, Baxter (Fenwal Division). 
acid and ionic content of both solutions are shown in Table I.

After sterilization of all the bottle caps with tincture of iodine, $13 \mathrm{mEq}$ potassium chloride and $5 \mathrm{ml}$ multivitamin infusion (m.v.i.)* were added to each $500 \mathrm{ml}$ bottle $5 \%$ protein hydrolysate $/ 5 \%$ dextrose.t The required volumes of this and of the $50 \%$ glucose solution were then run off into the plastic packs, through the suitably adapted filling tube attached. Each bottle was vented through a $0.22 \mu \mathrm{m}$ millipore filter. The filling tubes of the packs of solution were finally sealed.

The risk of contamination of the solutions during manufacture is reduced by the use of a laminar air flow hood or similar system. The packs of solution could not be sterilized after manufacture and they were therefore stored until use at $4^{\circ} \mathrm{C}$, and not used if over 48 hours old.

TABLE I

Essential amino acid and mineral content of solutions

\begin{tabular}{l|c|c}
\hline & $\begin{array}{c}\text { Solution I } \\
\text { (per l.) }\end{array}$ & $\begin{array}{c}\text { Solution II } \\
\text { (per 1.) }\end{array}$ \\
\hline $\begin{array}{l}\text { Amino acids } \\
\text { Leucine }\end{array}$ & $\begin{array}{l}2.94 \mathrm{~g} \\
\text { Valine }\end{array}$ & $3.42 \mathrm{~g}$ \\
Lysine & $2.94 \mathrm{~g}$ & $3.42 \mathrm{~g}$ \\
Isoleucine & $2.2 \mathrm{~g}$ & $2.6 \mathrm{~g}$ \\
Phenylalanine & $1.86 \mathrm{~g}$ & $2.17 \mathrm{~g}$ \\
Threonine & $1.43 \mathrm{~g}$ & $1.7 \mathrm{~g}$ \\
Methionine & $1.36 \mathrm{~g}$ & $1.6 \mathrm{~g}$ \\
Histidine & $930 \mathrm{mg}$ & $1.1 \mathrm{~g}$ \\
Tryptophane & $930 \mathrm{mg}$ & $1.1 \mathrm{~g}$ \\
& $250 \mathrm{mg}$ & $290 \mathrm{mg}$ \\
Minerals & & \\
Sodium & $24.0 \mathrm{mEq}$ & $28.0 \mathrm{mEq}$ \\
Potassium & $32.0 \mathrm{mEq}$ & $37.5 \mathrm{mEq}$ \\
Calcium & $3.5 \mathrm{mEq}$ & $4.0 \mathrm{mEq}$ \\
Magnesium & $1.5 \mathrm{mEq}$ & $1.7 \mathrm{mEq}$ \\
Chloride & $14.0 \mathrm{mEq}$ & $17.0 \mathrm{mEq}$ \\
Phosphate & $21.5 \mathrm{mEq}$ & $25.0 \mathrm{mEq}$ \\
\hline
\end{tabular}

Note: The excess of cations was balanced by anions from the amino acids and stabilizers.

Insertion of the central venous catheters. Silastic catheters, which are probably less likely to perforate the blood vessels than those of more rigid material, were introduced into the right atrium by cutdown operation over an internal jugular vein. The operation was performed under general anaesthesia with strict asepsis in an operating theatre. As has been previously recommended to minimize infection of the blood stream, the venous catheters were tunnelled through the subcutaneous tissues from the vein entry point to a skin exit site $5 \mathrm{~cm}$ or more away onto the scalp behind the ear (Harries, 1971; Filler and Eraklis, 1970).

Method of administration of the basic solution. The solution was infused from the plastic pack into the central venous catheter through an administration set, without a connected venting tube. $\ddagger$ A $0.22 \mu \mathrm{m}$

$\star$ S.A.S. Scientific Chemicals Ltd., Liverpool.

†Amigen/dextrose solution.

¥BRIO Administration set, Baxter (Travenol Division). millipore filter was inserted in line immediately proximal to the central venous catheter, to act as a final barrier to particulate matter and micro-organisms before the solution entered the patient's blood stream.

In small infants a constant rate infusion pump is essential to control within narrow limits the volume of fluid administered. Over-transfusion of such hypertonic solutions carries a very great risk from osmotic overload. The pump used must be accurately calibrated to ascertain the relation of the rate of infusion of fluid to the speed of the pump and to the calibre of tubing used in the administration system. Further checks on the volume of fluid being delivered were made by either suspending the packs from a Fenwal infusion scale or by having a Pedatrol* in line in the system. Administration sets with burettes that require venting were not used, as they would have removed the advantage of eliminating contamination of the solutions by unsterile outside air afforded by the plastic packs.

The osmolality of the more concentrated solution I was 1350 to $1400 \mathrm{mOsm} / \mathrm{l}$. Because of the high risk of thrombophlebitis such solutions cannot be infused into peripheral veins. The large blood flow through the superior vena cava allows prolonged infusion via central venous catheters. No case of thrombosis within the superior vena cava or its major tributaries was experienced in the present series of patients. The high glucose concentration accounts for most of the osmolality. $18 \%$ glucose solutions contain approximately 1000 $\mathrm{mOsm} / \mathrm{l}$. The patient's ability to deal with the osmotic load was monitored by frequent measurements of the blood glucose concentration during treatment.

At the onset of parenteral alimentation, about 150 $\mathrm{ml} / \mathrm{kg}$ body weight per 24 hours of the less concentrated solution II was transfused at a constant rate. It was usually possible to introduce solution I after 4 to 5 days without producing hyperglycaemia. During the early days of therapy, accurate measurements of fluid intake and output, frequent testing of the urine for sugar, daily serum electrolytes and blood glucose estimations, and twice-daily weighings are required to detect an osmotic overload or diuresis as early as possible. Blood glucose levels should be maintained below $150 \mathrm{mg} / 100 \mathrm{ml}$.

At an infusion rate of $150 \mathrm{ml} / \mathrm{kg}$ per day, solution I supplied $3.6 \mathrm{mEq} / \mathrm{kg}$ per day sodium, $4.3 \mathrm{mEq}$ potassium, $0.23 \mathrm{mEq}$ magnesium, and $1.14 \mathrm{~g}$ nitrogen. Solution II supplied $4 \cdot 2 \mathrm{mEq} / \mathrm{kg}$ per day sodium, $5 \cdot 6$ $\mathrm{mEq}$ potassium, $0.25 \mathrm{mEq}$ magnesium, and $1.33 \mathrm{~g}$ nitrogen.

In addition to the basic solutions I and II, patients also received folic acid $5 \mathrm{mg}$ and vitamin $K 1 \mathrm{mg}$ intramuscularly twice weekly; plasma $20 \mathrm{ml} / \mathrm{kg}$ body weight intravenously weekly; Imferon $0.5 \mathrm{ml}$ intramuscularly every 2 weeks; and vitamin $B_{12} 100 \mu \mathrm{g}$ intramuscularly monthly. These injections supplied essential vitamins not contained in the m.v.i., and minerals including trace elements not supplied by the basic solutions (Harries, 1971).

At the end of treatment the intravenous glucose

^Baxter (Travenol Division). 
concentration was gradually reduced by infusing $5 \%$ dextrose for 12 to 24 hours. Sudden termination of hypertonic glucose administration carries a danger of hypoglycaemia.

\section{Bacteriological studies during parenteral alimentation}

Blood cultures. 17 patients aged from 1 day to 12 months were fed intravenously via 21 indwelling central venous catheters. The catheters were maintained in situ from 4 to 48 days (Table II) and for an average of 24 days. In Table II the diagnoses and the reasons for parenteral alimentation of each patient are also shown.

At least one $5 \mathrm{ml}$ specimen of blood obtained from each infant through the indwelling catheter was cultured for micro-organisms. $2 \mathrm{ml}$ blood was incubated aerobically at $37^{\circ} \mathrm{C}$ in bottles containing $100 \mathrm{ml}$ heart infusion broth with $0.15 \%$ glucose and $1 \mathrm{ml}$ added liquoid penase (see below for details of this preparation). Subcultures were

\section{TABLE II}

Details of total intravenous alimentation

\begin{tabular}{|c|c|c|}
\hline Age & $\begin{array}{l}\text { Duration of } \\
\text { intravenous } \\
\text { catheterization (dy) }\end{array}$ & $\begin{array}{l}\text { Indications for intravenous } \\
\text { alimentation }\end{array}$ \\
\hline $1 \mathrm{dy}$ & $\begin{array}{lr}\text { (1) } & 42 \\
\text { (2) } & 7\end{array}$ & $\begin{array}{l}\text { Gastroschisis and jejunal } \\
\text { perforation; ileal atresia; } 2 \\
\text { laparotomies }\end{array}$ \\
\hline $1 \mathrm{dy}$ & 21 & Gastroschisis \\
\hline 4 dy & 7 & $\begin{array}{l}\text { Primary repair of oesophageal } \\
\text { atresia; prematurity and } \\
\text { persistent hypoglycaemia }\end{array}$ \\
\hline $4 d y$ & 25 & $\begin{array}{l}\text { Multiple intestinal perforations; } \\
\text { intraperitoneal catheter tip } \\
\text { after intrauterine transfusion }\end{array}$ \\
\hline $11 \mathrm{dy}$ & 10 & $\begin{array}{l}\text { Atresia and perforation of the } \\
\text { colon; intraperitoneal abscess }\end{array}$ \\
\hline 2 wk & 28 & $\begin{array}{l}\text { Jejunal atresia; colonic } \\
\text { perforation; } 3 \text { laparotomies }\end{array}$ \\
\hline 2 wk & $\begin{array}{l}\text { (1) } 48 \\
\text { (2) } 25\end{array}$ & $\begin{array}{l}\text { Meconium ileus; recurrent } \\
\text { postoperative intestinal } \\
\text { obstruction; } 3 \text { laparotomies }\end{array}$ \\
\hline $1 \mathrm{mth}$ & 40 & $\begin{array}{l}\text { Meconium ileus with ileal } \\
\text { perforation; postoperative } \\
\text { monosaccharide intolerance } \\
\text { and intractable diarrhoea }\end{array}$ \\
\hline 6 wk & 13 & $\begin{array}{l}\text { Gastroenteritis and intractable } \\
\text { diarrhoea }\end{array}$ \\
\hline 6 wk & 29 & $\begin{array}{l}\text { Necrotizing enterocolitis; ileal } \\
\text { and colonic perforations }\end{array}$ \\
\hline $2 \mathrm{mth}$ & $\begin{array}{l}\text { (1) } 24 \\
\text { (2) } 25\end{array}$ & $\begin{array}{l}\text { Secondary monosaccharide } \\
\text { intolerance and intractable } \\
\text { diarrhoea }\end{array}$ \\
\hline $\begin{array}{l}2 \mathrm{mth} \\
2 \mathrm{mth}\end{array}$ & $\begin{array}{l}15 \\
24\end{array}$ & $\begin{array}{l}\text { Intractable diarrhoea } \\
\text { Intractable diarrhoea }\end{array}$ \\
\hline 2 mth & 36 & $\begin{array}{l}\text { Hirschsprung's disease of total } \\
\text { colon; postoperative diarrhoea } \\
\text { and malnutrition }\end{array}$ \\
\hline $3 \mathrm{mth}$ & $\begin{array}{lr}\text { (1) } & 40 \\
\text { (2) } & 4\end{array}$ & $\begin{array}{l}\text { Dysmaturity and failure to } \\
\text { thrive; Monosaccharide } \\
\text { intolerance and intractable } \\
\text { diarrhoea }\end{array}$ \\
\hline $10 \mathrm{mth}$ & 15 & $\begin{array}{l}\text { Coeliac disease; intractable } \\
\text { diarrhoea and vomiting }\end{array}$ \\
\hline 12 mth & 26 & $\begin{array}{l}\text { Immune deficiency; chronic } \\
\text { pneumonia; intractable } \\
\text { diarrhoea and malnutrition }\end{array}$ \\
\hline
\end{tabular}

made onto blood and chocolate agar after 7 days, or $\Omega$ earlier if there was a positive growth. $2 \mathrm{ml}$ blood was incubated anaerobically at $37^{\circ} \mathrm{C}$ in $100 \mathrm{ml}$ thioglycollate ? medium. Aerobic and anaerobic subcultures were made $\overrightarrow{\bar{F}}$ onto blood and chocolate agar after 7 days or when there was a positive growth. $1 \mathrm{ml}$ blood was added to liquoid penase medium $(0.3 \%$ liquoid in $0.9 \%$ saline with $2 \%$ penase (penicillinase)) and a pour plate onto heart

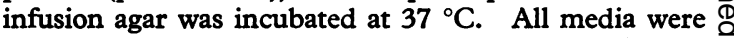
examined daily, and positive growths were sub-cultured.

Blood cultures were obtained at the slightest suspicion of systemic infection. Only two cases had clinical or $\overrightarrow{0}$ bacteriological evidence of septicaemia during parenteral $\overrightarrow{-}$ feeding, after 25 days and 40 days of such treatment, $\vec{\omega}$ respectively (Table III). Therefore, cultures of blood obtained from the intravenous catheters showed that only $9 \%$ of the catheters became colonized by microorganisms. In each case the responsible organism was a coagulase negative staphylococcus, and no instance of systemic candidiasis was encountered.

The infected patients were 2 months and 3 months old. They both required complete parenteral feeding for chronic intractable diarrhoea. The infections were successfully eradicated by removal of the catheters and appropriate antibiotic treatment.

Cultures of the packs of solution. Random bacteriological examinations were made on the solutions prepared in the plastic packs. Packs of solutions were cultured after storage at room temperature for up to 6 months. All such cultures were sterile, indicating that the aseptic techniques used in the manufacture of the packs of solution were satisfactory.

TABLE III

Results of blood cultures (taken via indwelling catheter)

\begin{tabular}{|c|c|c|c|}
\hline Patient & $\begin{array}{l}\text { Duration of } \\
\text { catheter (dy) }\end{array}$ & $\begin{array}{l}\text { No. of } \\
\text { cultures }\end{array}$ & $\begin{array}{l}\text { Results of } \\
\text { cultures }\end{array}$ \\
\hline $\begin{array}{r}1 \\
2 \\
3 \\
4 \\
5 \\
6 \\
7 \\
8 \\
9 \\
10 \\
11\end{array}$ & $\begin{array}{rr}\text { (1) } 42 \\
\text { (2) } 7 \\
21 \\
7 \\
75 \\
25 \\
10 \\
28 \\
\text { (1) } 48 \\
\text { (2) } 25 \\
40 \\
13 \\
29 \\
\text { (1) } 24 \\
\text { (2) } 25 \\
\\
15 \\
24 \\
36 \\
\text { (1) } 40 \\
\text { (2) } 4 \\
15 \\
26\end{array}$ & $\begin{array}{l}3 \\
1 \\
1 \\
1 \\
2 \\
1 \\
2 \\
4 \\
2 \\
2 \\
2 \\
3 \\
2 \\
5 \\
3 \\
2 \\
3 \\
3 \\
1 \\
3 \\
9\end{array}$ & $\begin{array}{l}\text { Sterile } \\
\text { Sterile } \\
\text { Sterile } \\
\text { Sterile } \\
\text { Sterile } \\
\text { Sterile } \\
\text { Sterile } \\
\text { Sterile } \\
\text { Sterile } \\
\text { Sterile } \\
\text { Sterile } \\
\text { Sterile } \\
\text { Sterile } \\
\text { Staph. } \\
\text { albus in } 2 \\
\text { Sterile } \\
\text { Sterile } \\
\text { Sterile } \\
\text { Staph. } \\
\text { albus in } 1 \\
\text { Sterile } \\
\text { Sterile } \\
\text { Sterile }\end{array}$ \\
\hline
\end{tabular}




\section{Discussion}

Systemic infection is the most frequent serious complication of parenteral alimentation (Moore and Brennan, 1972). Contamination of the infusion system and the patient's blood stream by microorganisms can occur in several ways.

Local infection at the entry site of the intravenous catheter is a potential precursor to septicaemia. Strict asepsis during the insertion of the catheter is essential and separation of the venous entry site from the skin entry of the catheter probably reduces the risk of septicaemia (Filler and Eraklis, 1970; Harries, 1971). The skin entry site of the catheter was covered with antibacterial and antifungal dressings and these were not changed more than once weekly. Change of dressings have been recommended every 2 to 3 days (Grant, Moir, and Fago, 1969), but Colvin et al. (1972) had a low incidence of infection without any change of dressings.

The infused solutions are excellent culture media for micro-organisms (Shadomy and Shadomy, 1972; Brennan et al., 1972) and therefore extreme care was taken to prevent their contamination both during their manufacture in the plastic packs and during the changing of the packs and of the administration sets, which was the responsibility of restricted members of the medical and nursing staff.

The solutions were contained in collapsible plastic packs as they allowed an infusion system which was nonvented and completely closed to the unsterile outside air to be used (Rupp and Forni, 1972).

Packs of solutions were manufactured aseptically as they could not be sterilized afterwards. Contamination during such procedures could not be completely guaranteed, but cultures of packs of solution were all sterile. Packs of solution were stored at $4{ }^{\circ} \mathrm{C}$ until given to patients and were not used if over $\mathbf{4 8}$ hours old. These precautions were carried out not only to reduce the risk of possible contamination during manufacutre but to eliminate possible chemical alterations within the solutions, such as the formation of amino acid-sugar complexes (Coats, 1972).

Junctions within the infusion system, e.g. between the intravenous catheters, the administration sets, and the packs of solution, were potential sites of contamination by micro-organisms. The present regimen of fat-free parenteral feeding reduced such interconnexions to a minimum and eliminated the necessity for complicated systems with $Y$ connectors and 2- or 3-way taps, which significantly increases the danger of infection. Junctions within the present feeding regimen were sprayed with anti- biotic aerosols containing neomycin, polymyxin, and bacitracin whenever they were changed.

As the solutions infused did not contain fat, it was possible to use a millipore filter to prevent microorganisms within the solutions from entering the patient's blood stream.

Prophylactic antibiotics cannot be added to the packs of solution because of incompatibility with protein hydrolysates. Their use probably increases the risk of infection by Candida albicans (Boeckman and Krill, 1970). As this is the organism most frequently associated with intravenous feeding, their use is probably contraindicated.

Previously reported rates of infection during parenteral feeding through indwelling venous catheters have been between 25 and $45 \%$ of those treated (Lloyd-Still, Shwachman, and Filler, 1972). A wide variety of micro-organisms have been cultured from the blood stream during parenteral feeding. C. albicans is the most frequent cause of septicaemia (Curry and Quie, 1971), and such systemic candidiasis has carried a 45 to $50 \%$ mortality rate (Boeckman and Krill, 1970; Ashcraft and Leape, 1970).

In the present parenteral feeding regimen indwelling central venous catheters were maintained in situ for up to 7 weeks and for a mean duration of 24 days. The overall infection rate was $9 \%$, which is lower than previously reported.

It is probably impossible completely to eliminate the problem of infection associated with the prolonged use of central venous catheters. The infection rate associated with ventriculoatrial shunts in hydrocephalus is about $14 \%$ (Luthardt, 1970). The infection rate experienced during parenteral feeding was less even though the indwelling catheter was projecting through the skin and was used to infuse fluids capable of supporting the growth of micro-organisms. In the two cases of septicaemia experienced, the causative organism was a coagulase negative staphylococcus, the organism which most frequently colonizes ventriculoatrial shunts.

No case of $C$. albicans septicaemia occurred. It was possible to feed a malnourished infant who had a severe deficiency of both cellular and humoral immunity for 26 days by the parenteral route without developing a systemic infection.

I am indebted to Professor Charlotte M. Anderson for her advice and encouragement during this project, and am grateful to the physicians and surgeons of the Birmingham Children's Hospital for permission to treat and study their patients. I thank particularly $\mathrm{Mr}$. J. Corkery and Mr. M. Obeid who introduced most of the intravenous catheters, and Dr. K. Rogers for the bacteriological studies. 


\section{REFERENCES}

Ashcraft, K. W., and Leape, L. L. (1970). Candida sepsis complicating parenteral feeding. Fournal of the American Medical Association, 212, 454.

Banks, D. C., Yates, D. B., Cawdrey, H. M., and Harries, M. G. (1970). Infection from intravenous catheters. Lancet, 1, 443.

Boeckman, C. R., and Krill, C. E., Jr. (1970). Bacterial and fungal infections complicating parenteral alimentation in infants and children. Fournal of Pediatric Surgery, 5, 117.

Brennan, M. F., O'Connell, R. C., Rosol, J. A., and Kundsin, R. (1972). The growth of Candida albicans in nutritive solutions given parenterally. Archives of Surgery, 103, 705.

Coats, D. A. (1972). The place of ethanol in parenteral nutrition. In Parenteral Nutrition, p. 152. Ed. by A. W. Wilkinson. Churchill Livingstone, London.

Colvin, M. P., Blogg, C. E., Savege, T. M., Jarvis, J. D., and Strunin, L. (1972). A safe long-term infusion technique? Lancet, 2, 317.

Curry, C. R., and Quie, P. G. (1971). Fungal septicemia in patients receiving parenteral hyperalimentation. New England fournal of Medicine, 285, 1221.

Filler, R. M., and Eraklis, A. J. (1970). Care of the critically ill child: intravenous alimentation. Pediatrics, 46, 456.
Grant, J. A. N., Moir, E., and Fago, M. (1969). Parenteral hyperalimentation. Americal fournal of Nursing, 69, 2392.

Harries, J. T. (1971). Intravenous feeding in infants. Archives of Disease in Childhood, 46, 855.

Lloyd-Still, J. D., Shwachman, H., and Filler, R. M. (1972). Intravenous hyperalimentation in pediatrics. American fournal of Digestive Diseases, 17, 1043.

Luthardt, T. (1970). Bacterial infections in ventriculo-auricular shunt systems. Developmental Medicine and Child Neurology, 12, Suppl. 22, 105.

Moore, F. D., and Brennan, M. F. (1972). Intravenous feeding. New England Fournal of Medicine, 287, 862.

Rupp, C. A., and Forni, P. (1972). Formic i.v. therapy. New England fournal of Medicine, 286, 894.

Shadomy, S., and Shadomy, H. J. (1972). Growth of Candida in casein hydrolysate solutions. New England fournal of Medicine, 286, 612.

Wilmore, D. W., and Dudrick, S. J. (1968). Growth and development of an infant receiving all nutrients exclusively by vein. Fournal of the American Medical Association, 203, 860.

Correspondence to Dr. R. Nelson, Institute of Child Health, Francis Road, Birmingham B16 8ET. 